\title{
Acupuncture therapy for drug addiction
}

\author{
Farid Esmaeili Motlagh ${ }^{1,2,3}$, Fatimah Ibrahim ${ }^{12^{*}}$, Rusdi Abd Rashid ${ }^{3}$, Tahereh Seghatoleslam ${ }^{3,4}$ \\ and Hussain $\mathrm{Habi}^{3}$
}

\begin{abstract}
Acupuncture therapy has been used to treat substance abuse. This study aims to review experimental studies examining the effects of acupuncture on addiction. Research and review articles on acupuncture treatment of substance abuse published between January 2000 and September 2014 were searched using the databases ISI Web of Science Core Collection and EBSCO's MEDLINE Complete. Clinical trial studies on the efficacy of acupuncture therapy for substance abuse were classified according to substance (cocaine, opioid, nicotine, and alcohol), and their treatment protocols, assessments, and findings were examined. A total of 119 studies were identified, of which 85 research articles addressed the efficacy of acupuncture for treating addiction. There were substantial variations in study protocols, particularly regarding treatment duration, frequency of electroacupuncture, duration of stimulation, and choice of acupoints. Contradictory results, intergroup differences, variation in sample sizes, and acupuncture placebo effects made it difficult to evaluate acupuncture effectiveness in drug addiction treatment. This review also identified a lack of rigorous study design, such as control of confounding variables by incorporating sham controls, sufficient sample sizes, reliable assessments, and adequately replicated experiments.
\end{abstract}

\section{Background}

In 1997, the National Institutes of Health accepted acupuncture therapy as an acceptable procedure complementary to Western medicine [1]. Evidence for its therapeutic effects comes mainly from clinical practice and research into pain control, fibromyalgia, headaches, Parkinson's disease, schizophrenia, and depression [2]. Acupuncture therapy can be administered using either manual insertion of needles or electroacupuncture (EA), a mild electrical stimulation of acupoints. Extended acupuncture methods may involve finger pressure (acupressure) and laser therapy [3].

In 1985, Dr. M. Smith finalized the National Acupuncture Detoxification Association (NADA) protocol that is currently practiced in over 250 hospitals in the United Kingdom and United States [4]. In 1996, the World Health Organization accepted acupuncture as a treatment for drug abuse [5]. The latest modification to this treatment protocol was developed in 2005 by Dr. Ji Sheng

\footnotetext{
*Correspondence: fatimah@um.edu.my

${ }^{1}$ Department of Biomedical Engineering, Faculty of Engineering,

University of Malaya, 50603 Kuala Lumpur, Malaysia

Full list of author information is available at the end of the article
}

from Peking University, Beijing, China [6]. Currently, more than 700 addiction treatment centers use acupuncture as an adjunctive procedure [7].

Prominent effects of acupuncture are increases in the levels of enkephalin, epinephrine, endorphin, serotonin, norepinephrine, and dopamine in the central nervous system and plasma [8] that might mediate substance abuse. Acupuncture has been used to treat addiction for three decades [2-89]. For example, auricular acupuncture (AA) is effective in treating alcohol and drug abuse in both Europe and the United States [4].

However, several clinical trials have indicated that acupuncture was not effective in treating addiction $[2,3$, $31,67,69,78-80]$. Thus, the efficacy of the NADA protocol has been reassessed over the last decade [7]. Several factors have been studied to evaluate the efficacy of acupuncture therapy; for example, treatment protocol, choice of acupoints, duration of acupuncture, study design diversity, sample size, addiction history, and assessment techniques.

This study aims to review the published research on acupuncture therapy for substance abuse in relation to study type, authors, funding agencies, countries, agonist substances, and acupoints used for stimulation. 
Experimental studies published between January 2000 and September 2014 were systematically reviewed and analyzed to try to resolve the lack of agreement about acupuncture's efficacy for substance abuse.

\section{Review \\ Literature search}

A search of the ISI Web of Science Core Collection and EBSCOHost (MEDLINE Complete) databases for the period January 2000 to September 2014 was conducted to identify acupuncture clinical trials. Keywords, topics available in the databases, and titles were searched for the following terms: "acupuncture," "electroacupuncture," "acupoint stimulation," "transcutaneous," and "electrostimulation" as single words or combinations (total number of articles: 25 358). The results were refined to exclude non-English language materials. The preliminary findings of the first phase were refined by several parallel filters to identify documents relevant to acupuncture treatment of substance abuse. The operator between the filters was the "OR" command. Single, relevant words were selected for each filter and included any combination of the following: "alcohol," "addict," "opioid," "heroin," "cigarette," "nicotine," "tobacco," "cocaine," and "substance" as title, topic, keywords, or abstract text (total number of articles: 230) from both searched databases. The search results were collated and filtered to exclude proceedings papers and letters, yielding 161 studies. The abstracts of these documents were reviewed to exclude papers related to other addiction fields such as the Internet, food, or games; 119 documents comprised the refined, selected results. Three authors (FEM, RR, and TS) independently assessed studies for eligibility and crosschecked the material for study relevance. The publication selection process was shown in Fig. 1.

The articles were classified according to their specifications, including publication date, number of citations, source, authors, organization, and funding agencies. All original research papers were examined for their efficacy and method of treating different categories of addiction to agonist substances (e.g., cocaine, opioid and opiate, nicotine, alcohol, morphine). Original clinical trials that investigated the efficacy of acupuncture therapy were divided into six categories based on substance dependence (cocaine, opioid and opiate, nicotine, alcohol, morphine, and other substances) with a narrative review of their methods and results. Although morphine is an opioid, it has been assigned its own section because of the high number of publications on this topic. Heroin, methadone, and opiates are discussed in the opioid section.

The findings are discussed and compared according to type of addictive substance. There were 96 articles and 29 review papers; 83 articles were original investigations (76 of which were clinical trials of acupuncture efficacy), with 45 articles involving human beings and 38 involving animals. Figure 2 shows the percentage of all documents in each type of category. Original investigations of humans and animals were classified separately according to type of substance dependence. These articles placed more of an investigative emphasis on morphine and alcohol than on other substances.

The total number of citations for all documents was 1495 (mean $=15.83$ and standard deviation $=15.27$, citation range $2-87$ by excluding 29 articles cited zero times or only once). The top ten most cited articles were shown in Table 1. The United States (43 articles) and China (40 articles) published almost $70 \%$ of all articles. Among the Asian countries, China and South Korea published 59 articles, comprising $50 \%$ of publications. Their funding agencies were also the top supporters in this field. Peking, Kyung Hee, and Daegu Haany Universities were the top three organizations, publishing 40 articles since 2000.

The published articles were associated with various research areas (Fig. 3). About $80 \%$ of the articles focused on neuroscience and neurology, substance abuse, and integrative complementary medicine research areas. Published articles for each year were shown in Fig. 4.

Original experimental research articles were reviewed according to type of substance dependence (Fig. 2); the treatment method, subjects, objectives, and assessments of clinical trials for each group were shown in Tables 2, 3, $4,5,6,7$.

\section{Cocaine}

Avants and Margolin have evaluated the efficacy of AA for cocaine addiction treatment in four studies on human subjects. Although promising results were reported in their first study on 82 cocaine-dependent subjects [10], another study on 83 cocaine-dependent subjects found AA to be effective in reducing cocaine in only one of two trials [60]. When the original study was repeated with 620 subjects, no effect was found [61]. These researchers also conducted a study in 2005 on 40 cocaine abusers who had tested positive for the human immunodeficiency virus and were under methadone maintenance; no difference was found between the standard and reduced NADA protocols for cocaine use [59].

Three studies on rats were conducted to explore the effects of bilateral stimulation at the Shenmen (HT7) points. Modulation of the central dopaminergic system by acupuncture might be effective in preventing the behavioral effects of cocaine in rats [44]. By regulating neuronal activation in the nucleus accumbens (NAc) shell, acupuncture reduced stress-induced relapse [84]. The effect of acupuncture on the inhibition of cocaineinduced locomotor activity was mediated by A-fiber 


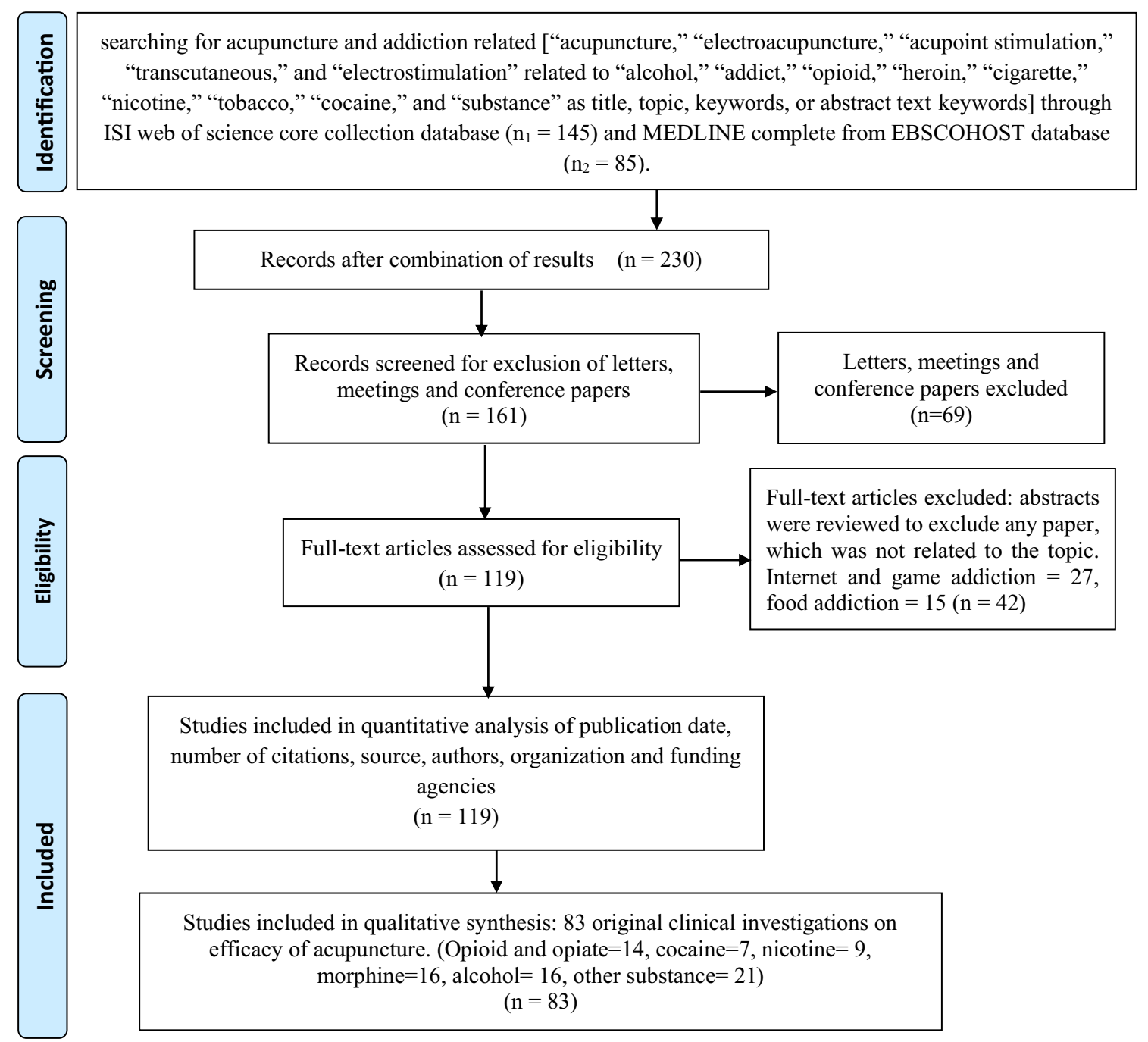

Fig. 1 Flow chart of selection process

activation of the ulnar nerve in rats [42]. See Table 2 for study details.

\section{Opioids and opiates}

In 2002, Montazeri investigated the efficacy of acupuncture at Hegu (LI4), Neiguan (PC6), Shenmen (HT7), Taichong (LR3), Zusanli (ST36), Dazhui (DU14), and Baihui (DU20) in 40 male adult heroin- or opium-addicted patients. The severity of withdrawal symptoms declined when acupuncture was used in rapid opiate detoxification [63]. Liu (2007) used functional magnetic resonance imaging to show that hypothalamus activation associated with manual acupuncture at Zusanli (ST36) was more robust in heroin addicts compared with healthy subjects [55]. EA (2 Hz) at Zusanli (ST36) and Sanyinjiao (SP6) was effective in reducing active responses elicited by discrete cues in rats [56]. The same EA treatment showed promise in treating heroin-seeking behaviors when combined with extinction therapy [33]. EA $(2 \mathrm{~Hz})$ at the same points-Zusanli (ST36) and Sanyinjiao (SP6)-activated the endogenous opioid cannabinoid and the dopamine systems in rats [81].

An evaluation of the event-related potentials of heroin addicts before and after acupuncture at Neiguan (PC6) and Zusanli (ST36) suggested that EA might potentially lower relapse rates by inhibiting attention bias to heroin [37]. The presentation of heroin cues could induce activation in craving-related brain regions, which are involved in reward, learning and memory, cognition, and emotion. Acupuncture at Zusanli (ST36) rapidly suppressed the activation of these specific brain regions related to craving [17]. Transcutaneous electric acupoint stimulation 


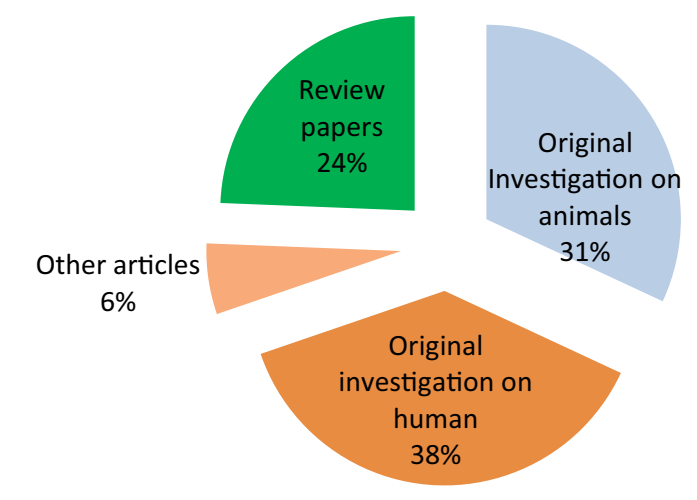

\begin{tabular}{cc}
\hline Article type & Number \\
\hline Original investigation on rats & 38 \\
Original investigation on human & 45 \\
Other articles & 7 \\
Review papers & 29 \\
Total & 119
\end{tabular}

Other substances

\section{Morphine}

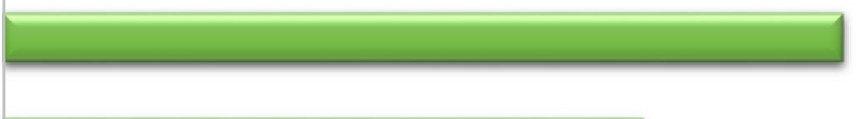

\section{Alcohole}

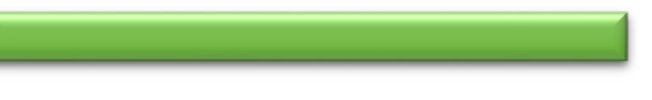

Alcohole

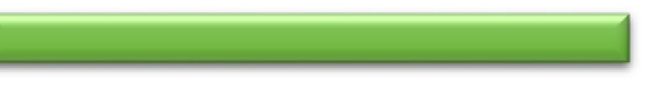

Nicotine

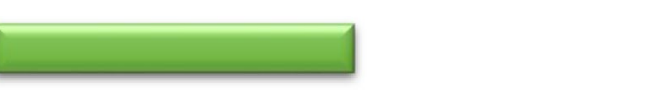

Hero

Cocaine

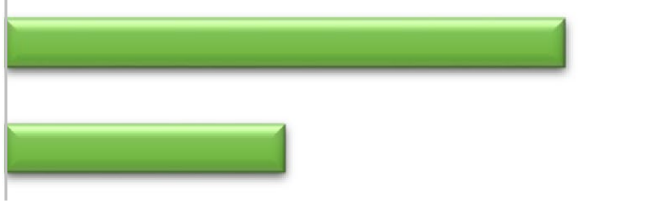

0

5

10

15

20

25

\section{Number of original investigations}

Fig. 2 Classification of selected articles into review papers and original investigations on humans and animals. The lower diagram shows the number of original clinical investigations according to substance. Morphine and alcohol have the most articles. Each of the columns is described separately in Tables 2, 3, 4, 5, 6, 7

was a possible adjunctive treatment to pharmacological treatments for heroin detoxification [62]. Acupuncture at Dazhui (GV14) and Baihui (DU20) prevented brain cell apoptosis in heroin-readdicted rats, normalized neuronal ultrastructure in the ventral tegmental area of heroin relapse rats, and protected nerve cells against injury in heroin relapse rats [32, 88].

Recent studies of acupuncture's effectiveness as an adjunct therapy in methadone maintenance programs have been controversial. In 2009, Bearn demonstrated a lack of effect for adjunctive methadone maintenance treatment with AA upon withdrawal severity or craving [11]. In 2013, Pei Lin showed a lack of AA effectiveness on the number of daily consumed cigarettes, relapse rate, and withdrawal symptoms, and examined patients' satisfaction and coping with AA as an adjunct treatment to methadone maintenance treatment among Malaysian subjects [57, 58]. However, Chan et al. [22] claimed that 2 weeks of acupuncture therapy reduced the daily dose of methadone and was also associated with greater improvement in sleep latency. See Table 3 for study details.

\section{Nicotine}

Acupuncture stimulation at Zusanli (ST36) exerted a therapeutic effect on nicotine detoxification [21] and acupuncture at Zusanli (ST36) or Shenmen (HT7) might attenuate anxiety-like behavior following nicotine withdrawal by modulating corticotrophin-releasing factor in the amygdala [20]. Smoking withdrawal symptoms could be ameliorated by acupuncture treatment [18]. In one study, acupuncture at Shenmen (HT7) attenuated 
Table 1 Top 10 most cited articles from 2000 to 2014

\begin{tabular}{|c|c|c|c|c|}
\hline Title & First author & Source title & $\begin{array}{l}\text { Publication } \\
\text { year }\end{array}$ & $\begin{array}{l}\text { Total } \\
\text { citations }\end{array}$ \\
\hline $\begin{array}{l}\text { Acupuncture: An evidence-based review of the } \\
\text { clinical literature [90] }\end{array}$ & Mayer DJ & Annual Review of Medicine & 2000 & 87 \\
\hline $\begin{array}{l}\text { A randomized controlled trial of auricular acu- } \\
\text { puncture for cocaine dependence [10] }\end{array}$ & Avants SK & Archives of Internal Medicine & 2000 & 67 \\
\hline $\begin{array}{l}\text { Acupuncture for the treatment of cocaine } \\
\text { addiction—a randomized controlled trial [61] }\end{array}$ & Margolin A & Journal of the American Medical Association & 2002 & 66 \\
\hline $\begin{array}{l}\text { Clinical research on acupuncture: Part I. What } \\
\text { have reviews of the efficacy and safety of } \\
\text { acupuncture told us so far? [91] }\end{array}$ & Birch S & $\begin{array}{l}\text { Journal of Alternative and Complementary } \\
\text { Medicine }\end{array}$ & 2004 & 64 \\
\hline $\begin{array}{l}\text { Peripheral neuropathy: Pathogenic mechanisms } \\
\text { and alternative therapies [92] }\end{array}$ & Head, Kathleen A & Alternative Medicine Review & 2006 & 50 \\
\hline $\begin{array}{l}\text { Acupuncture and related interventions for } \\
\text { smoking cessation [78] }\end{array}$ & White AR & Cochrane Database of Systematic Reviews & 2006 & 43 \\
\hline $\begin{array}{l}\text { A large randomized placebo controlled study of } \\
\text { auricular acupuncture for alcohol dependence } \\
\text { [16] }\end{array}$ & Bullock ML & Journal of Substance Abuse Treatment & 2002 & 41 \\
\hline $\begin{array}{l}\text { Peripheral electric stimulation inhibits mor- } \\
\text { phine-induced place preference in rats [75] }\end{array}$ & Wang B; Luo, F & NeuroReport & 2000 & 39 \\
\hline Acupuncture in clinical neurology [67] & Rabinstein AA & Neurologist & 2003 & 37 \\
\hline $\begin{array}{l}\text { Traditional Chinese medicine in treatment of } \\
\text { opiate addiction [93] }\end{array}$ & Shi, Jie & Acta Pharmacologica Sinica & 2006 & 34 \\
\hline
\end{tabular}

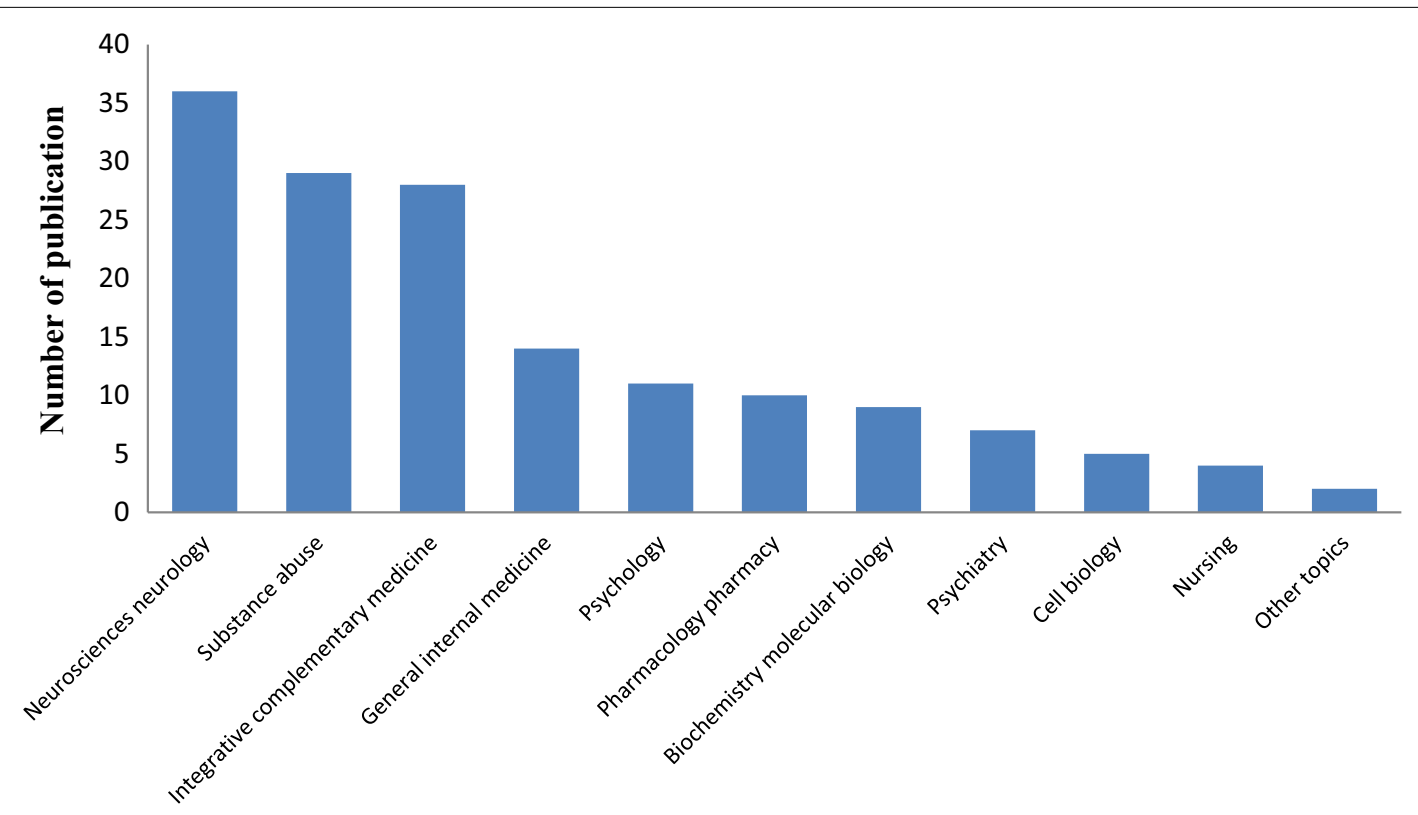

Fig. 3 Number of research articles in each area. Neuroscience, substance abuse, and complementary medicine are ranked highest

cigarette withdrawal symptoms more than acupuncture at Shousanli (LI10) [19]. Real acupuncture (as opposed to sham acupuncture) at Shenmen (HT7) alleviated cueinduced cravings through the regulation of activity in brain regions (medial prefrontal cortex, premotor cortex, amygdala, hippocampus, and thalamus) related to craving scores in the initial abstinence phase [38].
However, one study failed to find any effect of acupuncture on cotinine serum levels, carbon monoxide exhalation, and smoking quit rate in 59 smokers [83]. It has been suggested that DRD2 gene TaqI A polymorphism was related to AA response in smoking cessation treatment [65]. Auricular transcutaneous electrical neurostimulation relieved withdrawal symptoms and decreased 


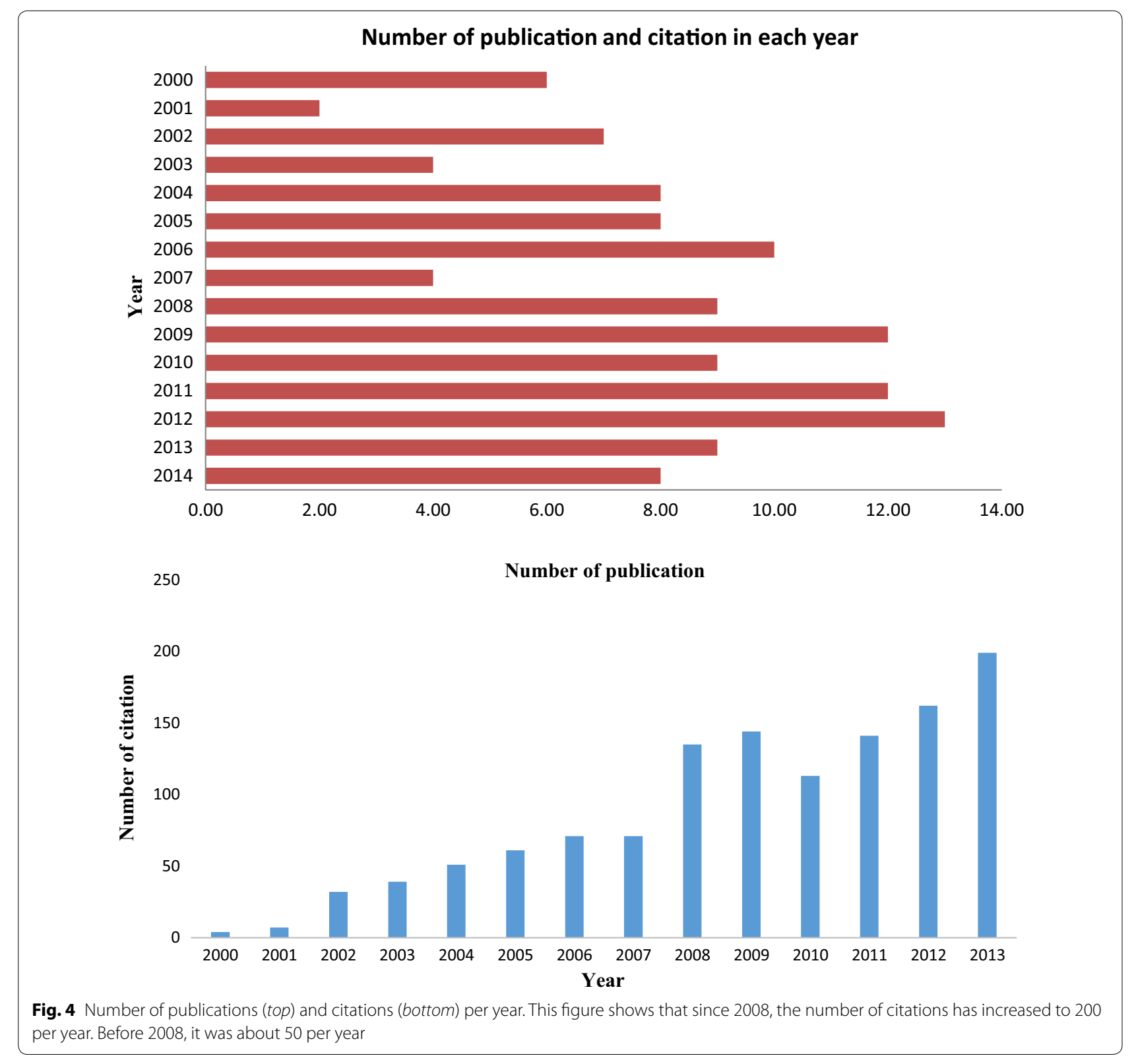

anxiety and stress levels during the detoxification period in a study of six smokers [15]. Auricular transcutaneous electrostimulation therapy might be an acceptable alternative therapy for smoking cessation [72]. See Table 4 for study details.

\section{Alcohol}

Conflicting results from two large randomized singleblind, placebo-controlled trials suggested that acupuncture was not effective in reducing alcohol use [16, 39]. However, promising results have been found using acupuncture as an adjunctive treatment to carbamazepine medication to reduce the severity of alcohol withdrawal symptoms [39]. In one study, AA failed to reduce the duration and severity of alcohol withdrawal symptoms [43]; another study found no advantage for laser AA in treating alcohol withdrawal [74]. However, research indicated that laser therapy helps to promote the release of endorphins in the body and decreases discomfort accompanying alcohol withdrawal [87]. It might therefore be a safe and painless beneficial adjunct treatment for alcoholism [87].

Acupuncture at Zusanli (ST36) or Sanyinjiao (SP6) modulated postsynaptic neural activation in the striatum 


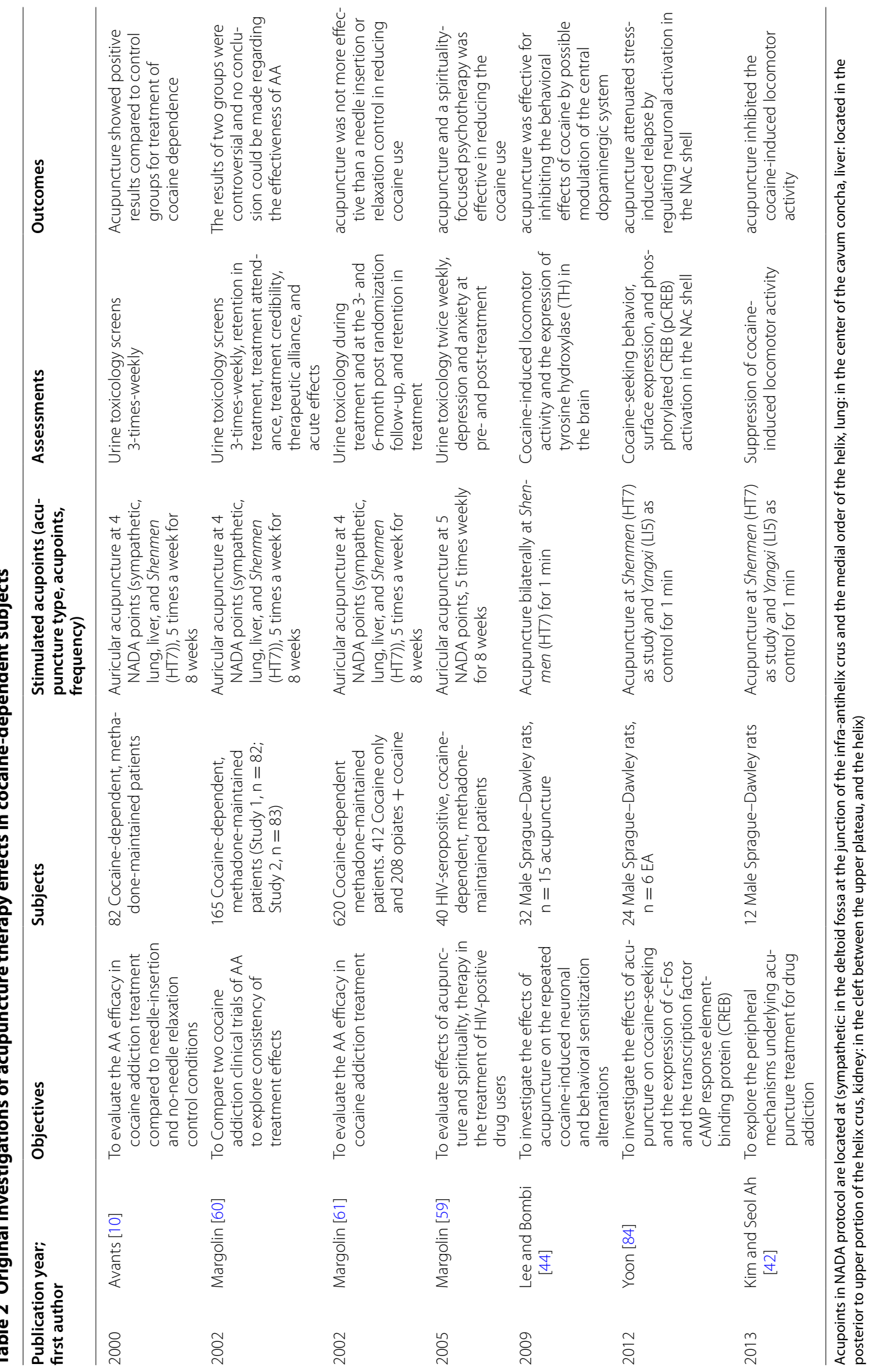




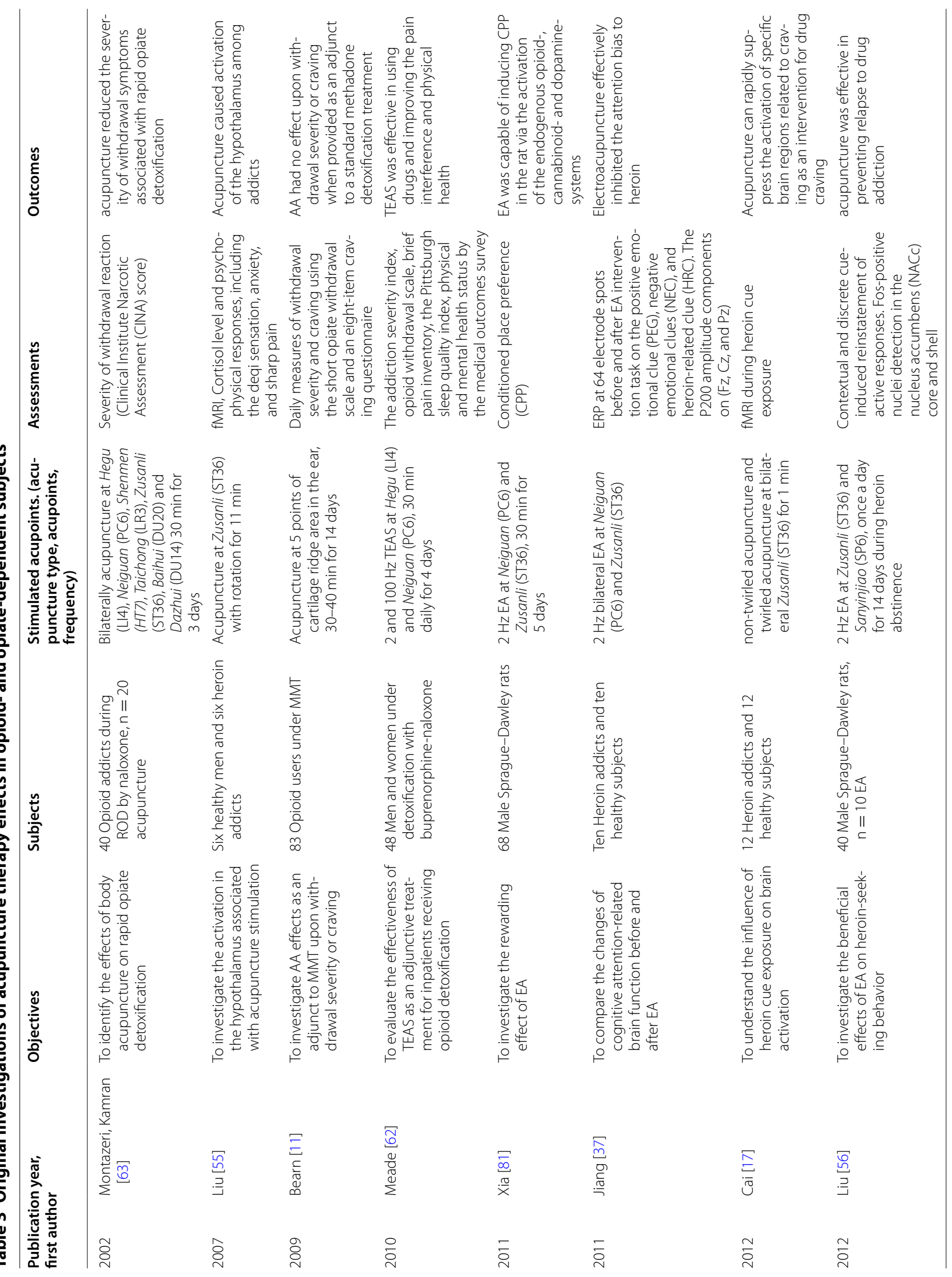




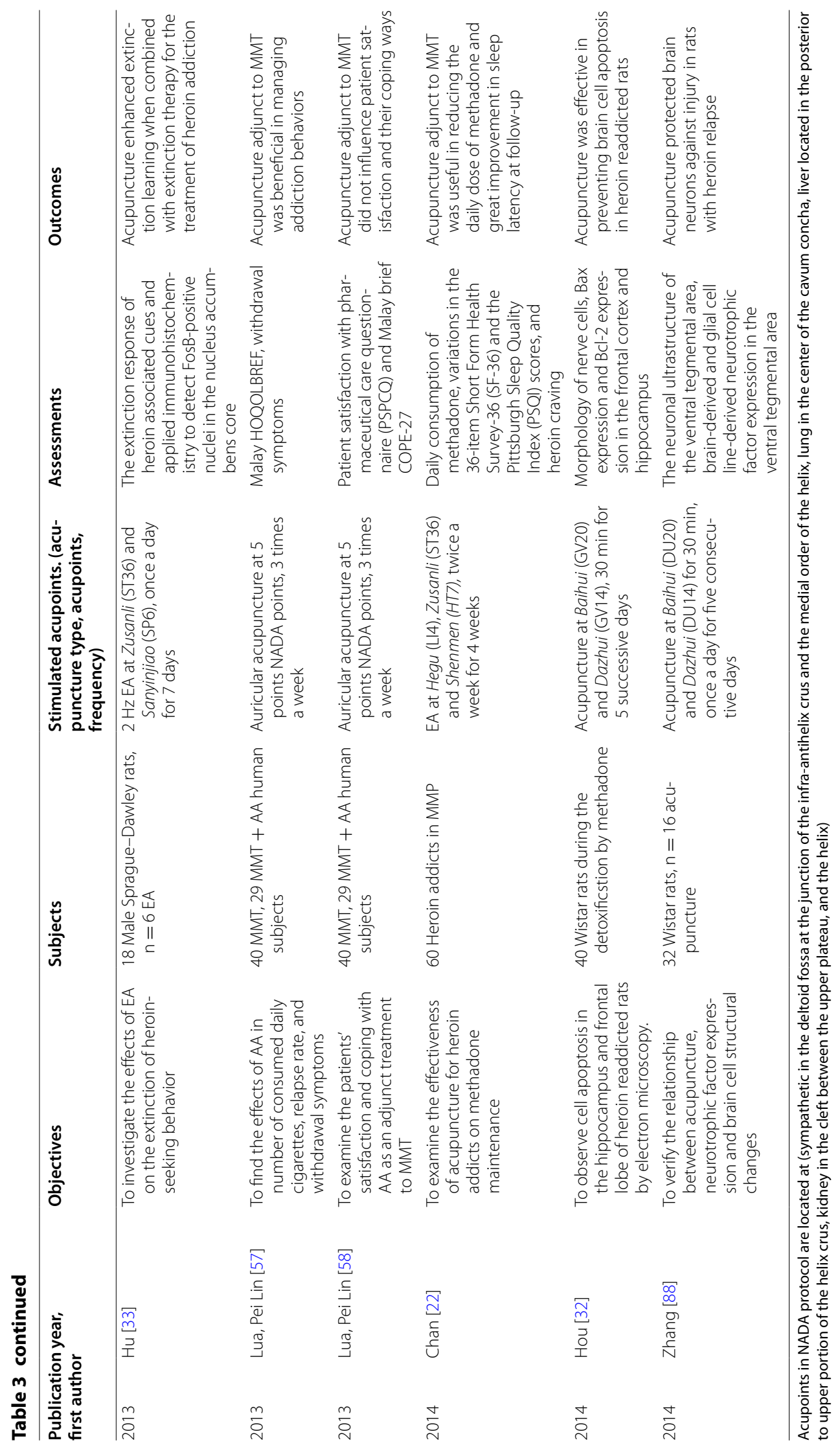




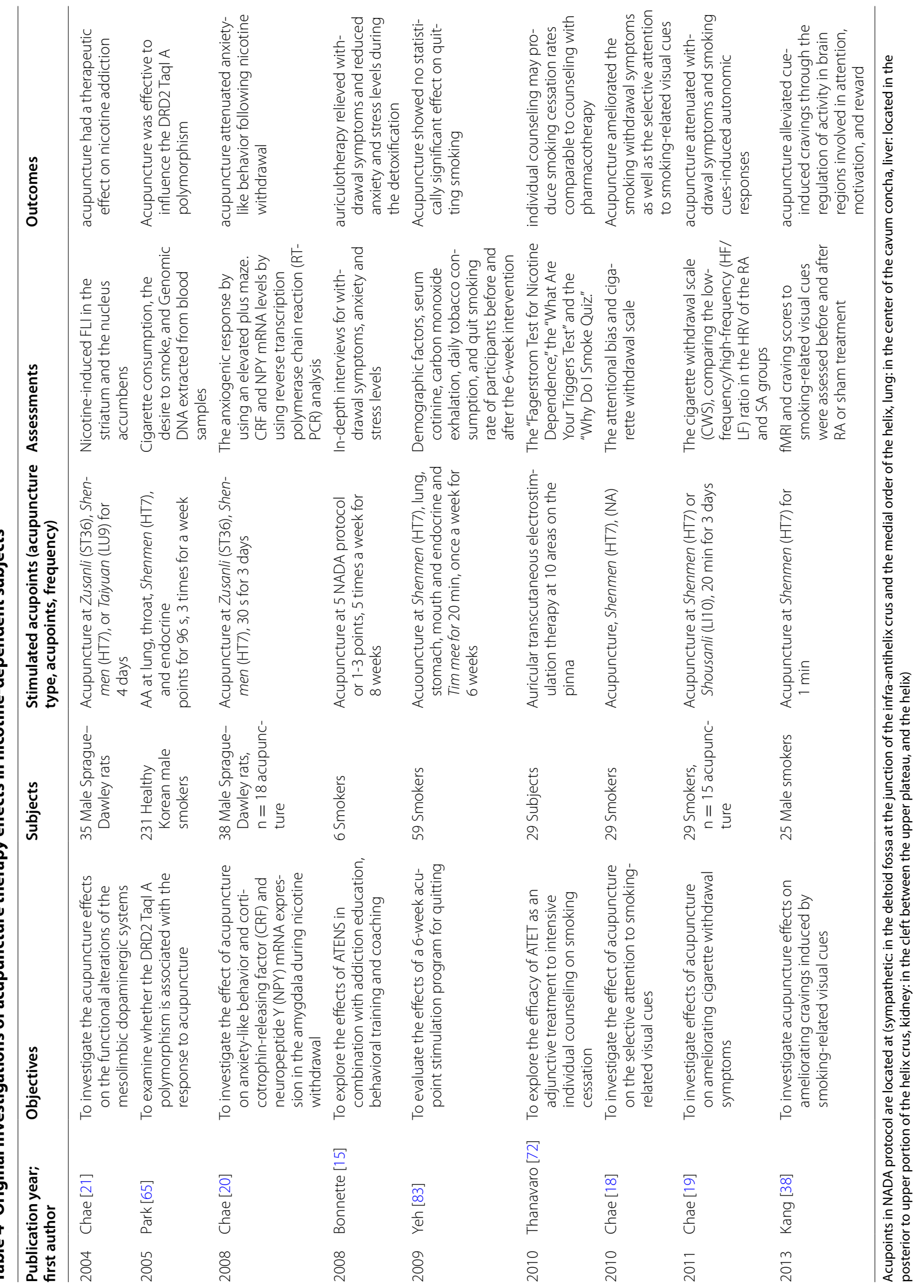




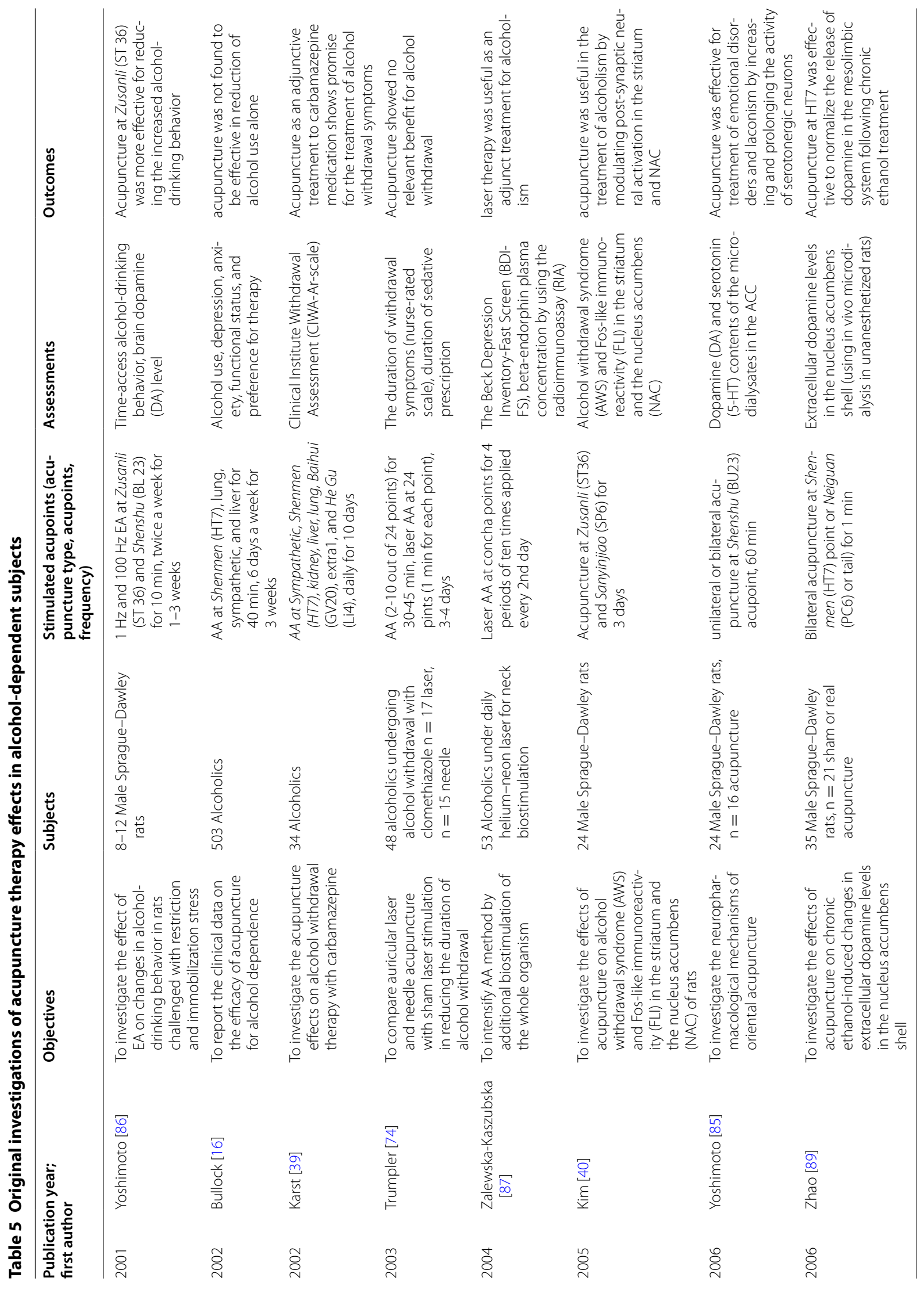




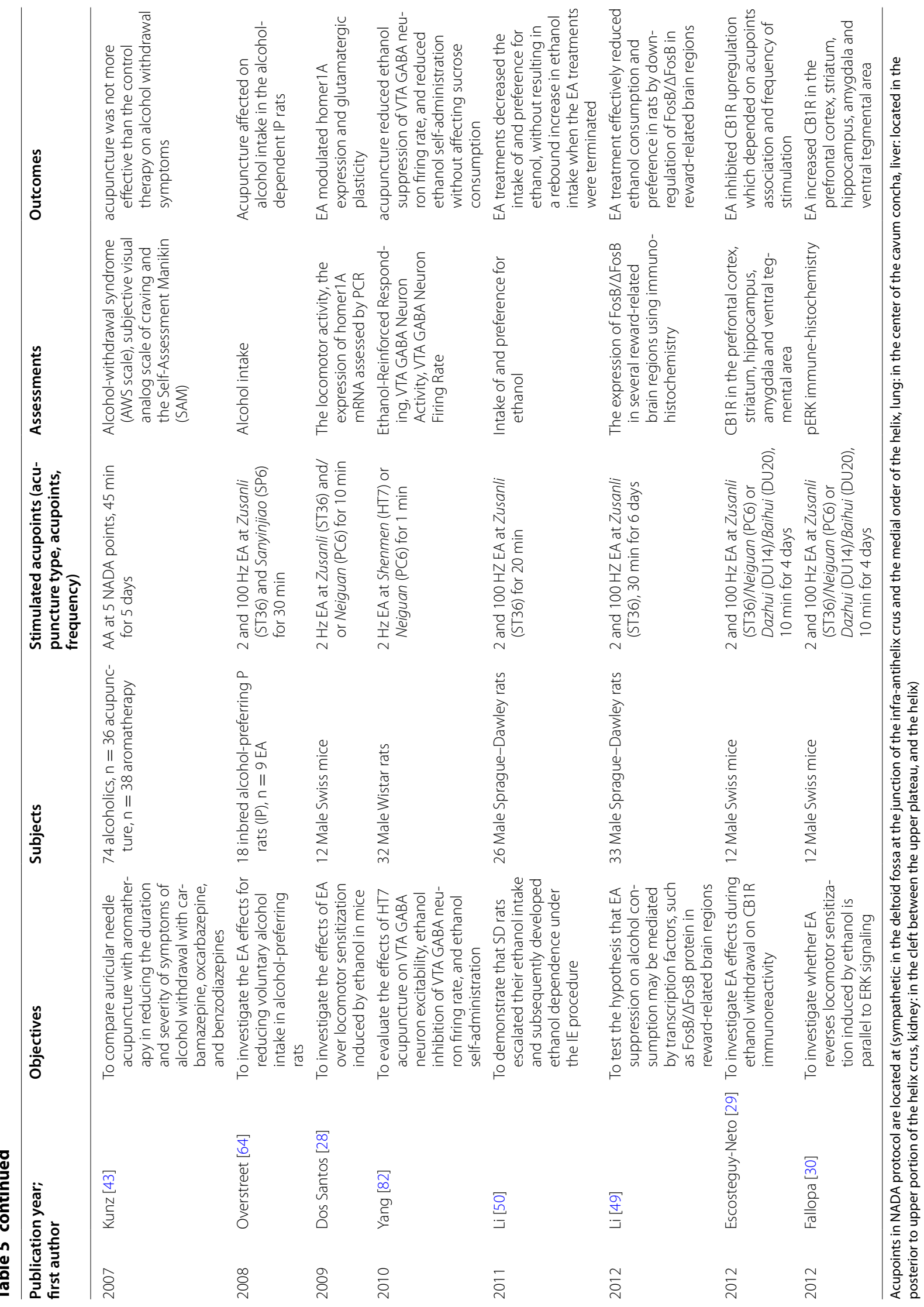


and NAc in rats [89]. Acupuncture at Shenmen (HT7) normalized dopamine release in the mesolimbic system [89], modulated mesolimbic dopamine release, and suppressed the reinforcing effects of ethanol [82]. Activation of the endogenous opiate system might be responsible for Zusanli (ST36) and Sanyinjiao (SP6) stimulation effects on alcohol intake in alcohol-dependent rats [64].

EA applied at Zusanli (ST36) was more effective than EA at Shenshu (BL23) at normalizing alcohol-drinking behavior in rats [86]; the activity of serotonergic neurons in the reward system pathway of the brain might be increased and prolonged by acupuncture [85]. EA at the combination Zusanli (ST36) and Neiguan (PC6) (but not at either point alone) prevented sensitization of the mesocorticolimbic pathway induced by ethanol in mice and modulated both the expression of the protein homer1A and glutamatergic plasticity [28]. EA $(2 \mathrm{~Hz})$ at Zusanli (ST36) could reduce voluntary intake of ethanol, but not sucrose, in rats [50] and $100 \mathrm{~Hz}$ EA treatment at Zusanli (ST36) effectively reduces preference for ethanol and its consumption in rats [49]. In one study, $2 \mathrm{~Hz}$ EA at Zusanli (ST36) and Neiguan (PC6) or $100 \mathrm{~Hz}$ EA at Dazhui (DU14) and Baihui (DU20) inhibited CB1R upregulation in ethanol-withdrawn mice [29]. The behavioral effects of $2 \mathrm{~Hz}$ EA at Dazhui (DU14) and Baihui (DU20), but not $100 \mathrm{~Hz}$ EA at Zusanli (ST36) and Neiguan (PC6), depended on extracellular signal-regulated kinase signaling [30]. See Table 5 for study details.

\section{Morphine}

Compared with $100 \mathrm{~Hz}, 2 \mathrm{~Hz}$ peripheral electric stimulation (PES) at Zusanli (ST36) and Sanyinjiao (SP6) inhibited the expression of morphine-induced conditioned place preference (CPP) (see [52] for information on CPP) via activation of opioid receptors [75]. One study found that the release and synthesis of enkephalin in the NAc was accelerated by $2 \mathrm{~Hz}$ stimulation of Zusanli (ST36) and Sanyinjiao (SP6) [53]. In addition, EA suppression of opiate addiction might involve the release of endogenous $\mu$-, $\delta$-, and $\kappa$-opioid agonists in the NAc shell [52] and might activate the cannabinoid, endogenous opioid, and dopamine systems to induce CPP in rats [81]. PES $(100 \mathrm{~Hz})$ at Zusanli (ST36) and Sanyinjiao (SP6) activated the suprasegmental $\delta$ - and $\mathrm{k}$-opioid receptors in the central nervous system, which cause the anticraving effects of PES in rats [70]. It was also found that the expression of preproenkephalin and preprodynorphin mRNAs in the NAc was mediated by $2 \mathrm{~Hz}$ or $100 \mathrm{~Hz}$ PES, with the release of endogenous $\mu-, \delta$-, and $k$-opioid agonists to suppress morphine-induced CPP [71]. Stimulation at Zusanli (ST36) and Sanyinjiao (SP6) $(100 \mathrm{~Hz})$ for $30 \mathrm{~min}$ normalized the activity of ventral tegmental area dopamine neurons [34], downregulated p-cAMP response element binding, and accelerated dynorphin synthesis in the spinal cord [76].

Some research suggests that $2 \mathrm{~Hz}$ EA is a potential complementary therapy for improving immune dysfunction in opiate addicts [51] and that $2 \mathrm{~Hz}$ or $100 \mathrm{~Hz}$ EA facilitates the recovery of male sexual behavior in rats during morphine withdrawal [27]. Thirty minutes of EA of $2 \mathrm{~Hz}$ or $100 \mathrm{~Hz}$ at Zusanli (ST36) and Sanyinjiao (SP6) reversed the morphological alterations induced by chronic morphine administration [25]. In addition, by increasing NREM sleep, REM sleep, and total sleep time, EA could be a potential treatment for sleep disturbance during morphine withdrawal [48].

EA at Shenshu (BL23) attenuated the expression of the proto-oncogene c-Fos in the central nucleus of the amygdala [54]. Acupuncture at Shenmen (HT7) inhibited neurochemical and behavioral sensitization to morphine by decreasing dopamine release in the NAc [41]. Acupuncture at Shenmen (HT7) significantly suppressed morphine-induced increase in locomotor activity and Fos expression in the NAc and striatum [45]. Acupuncture at Yanggu (SI5) can reduce the reinstatement of morphineseeking behaviors by mediating the gamma-aminobutyric acid receptor system [46, 47]. See Table 6 for study details.

\section{Other substances}

Studies of methamphetamine, cannabis, illicit/psychoactive drugs, and polydrug users are shown in Table 7. Twelve studies used the NADA 5-point protocol and AA as their treatment method. The findings indicated that people dependent on drugs preferred acupuncture treatment [9], which was associated with a decrease in psychological distress [12] and an increase in confidence [14], but showed no efficacy for drug consumption and withdrawal symptoms $[9,12-14]$. However, the conflicting nature of the research findings remains a controversial issue. Although there was evidence against the effectiveness of acupuncture in drug addiction treatment $[7,35,36]$, recent studies have shown an effect for AA $[23,24,26,68,73]$ and transcutaneous electric acupoint stimulation [66] per se or as adjunct treatments. Issues of safety and placebo effects suggest the need for further research $[26,35,36,66]$. See Table 7 for study details.

\section{Conclusion}

AA and NADA protocols failed to show a strong therapeutic effect for cocaine, nicotine, and alcohol addiction treatment. However, some studies discussed here 


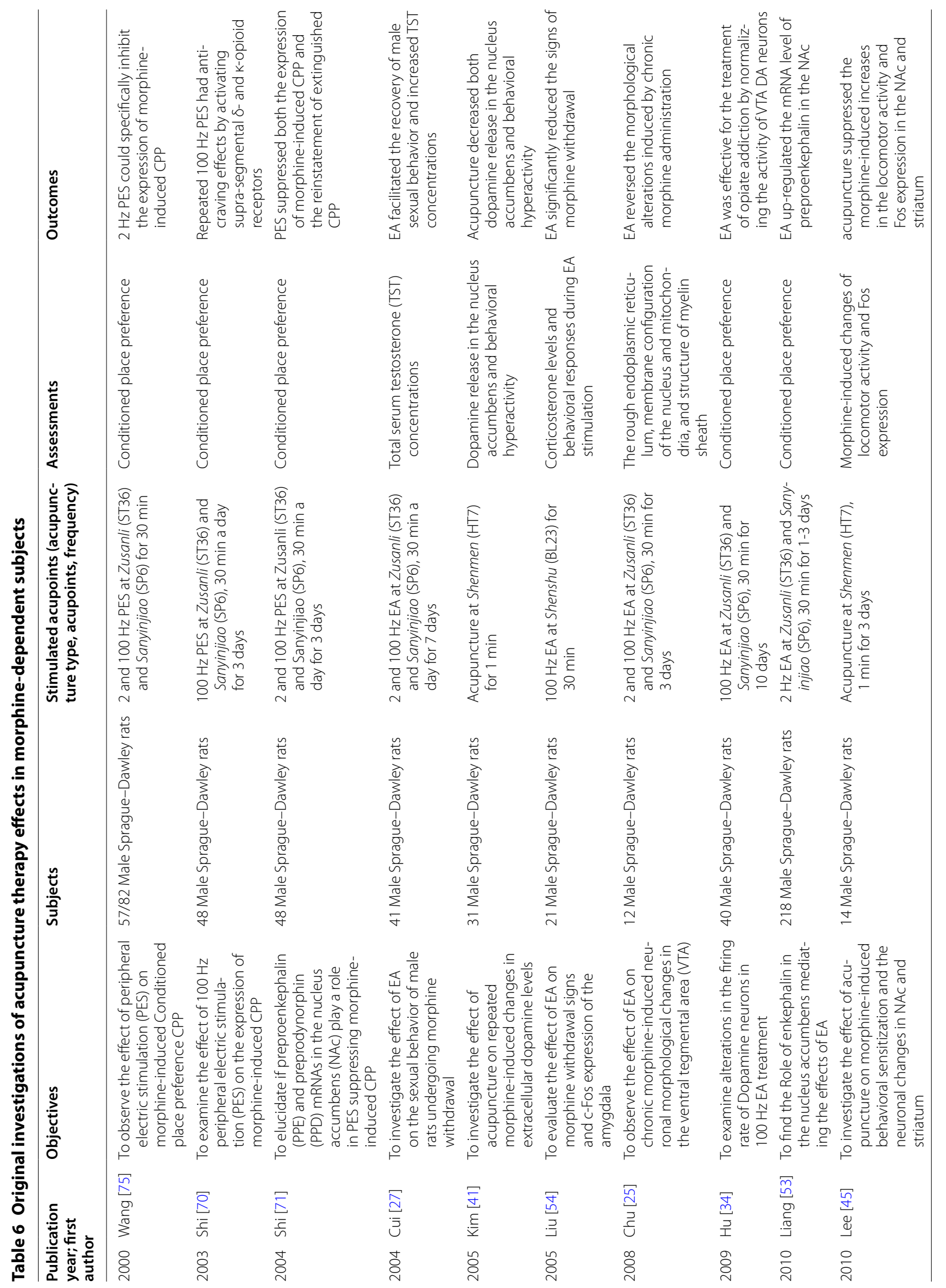




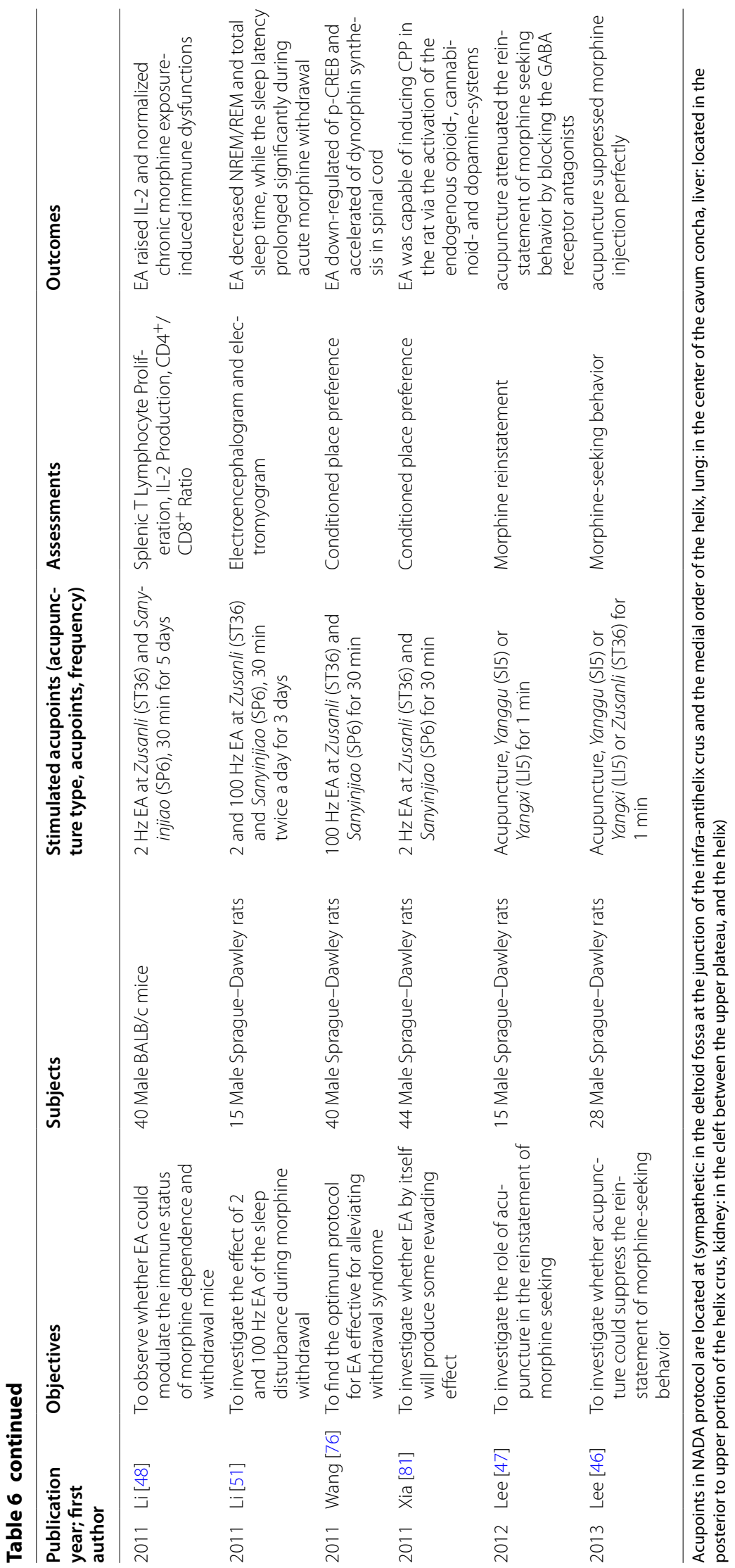




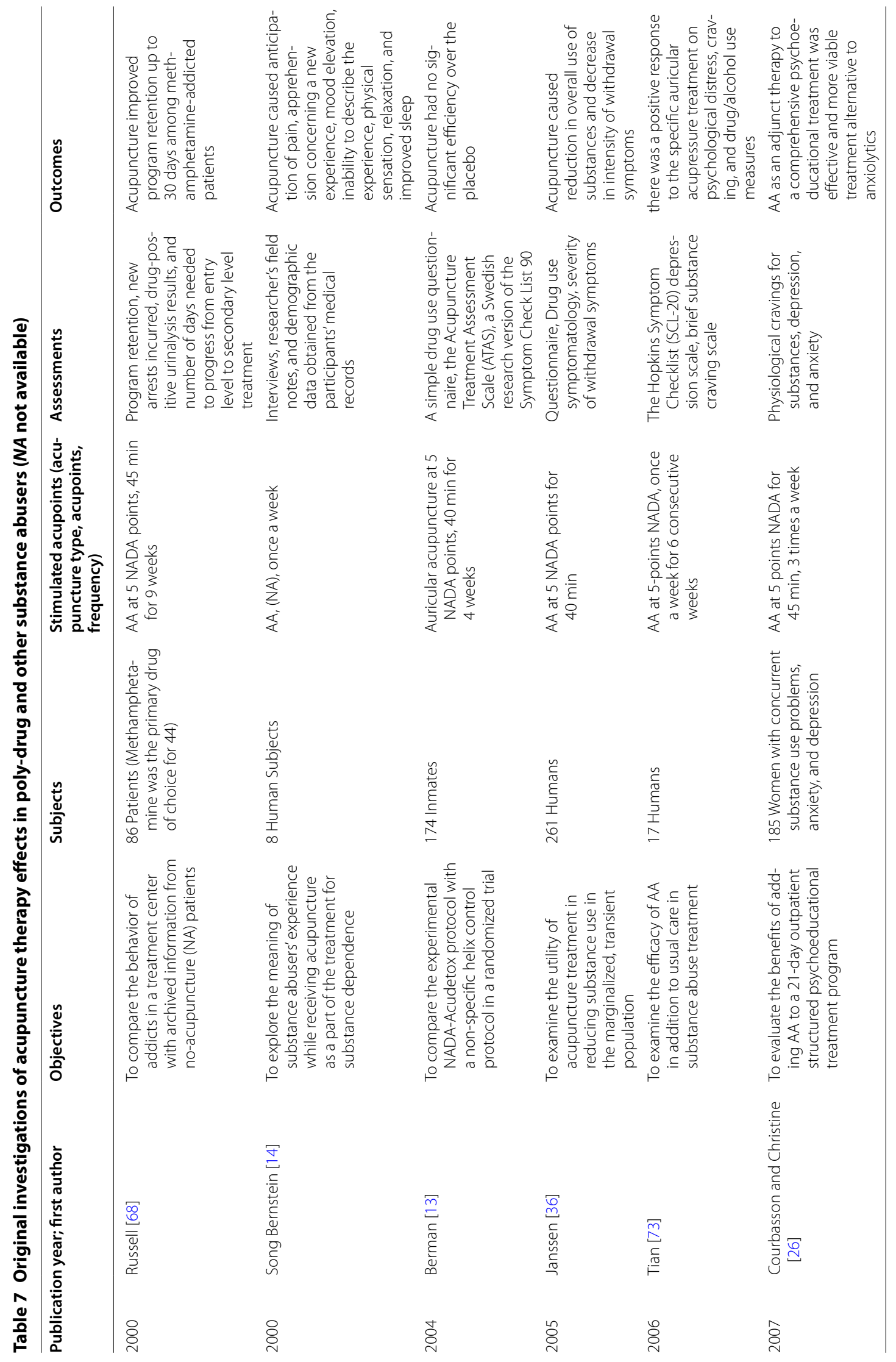




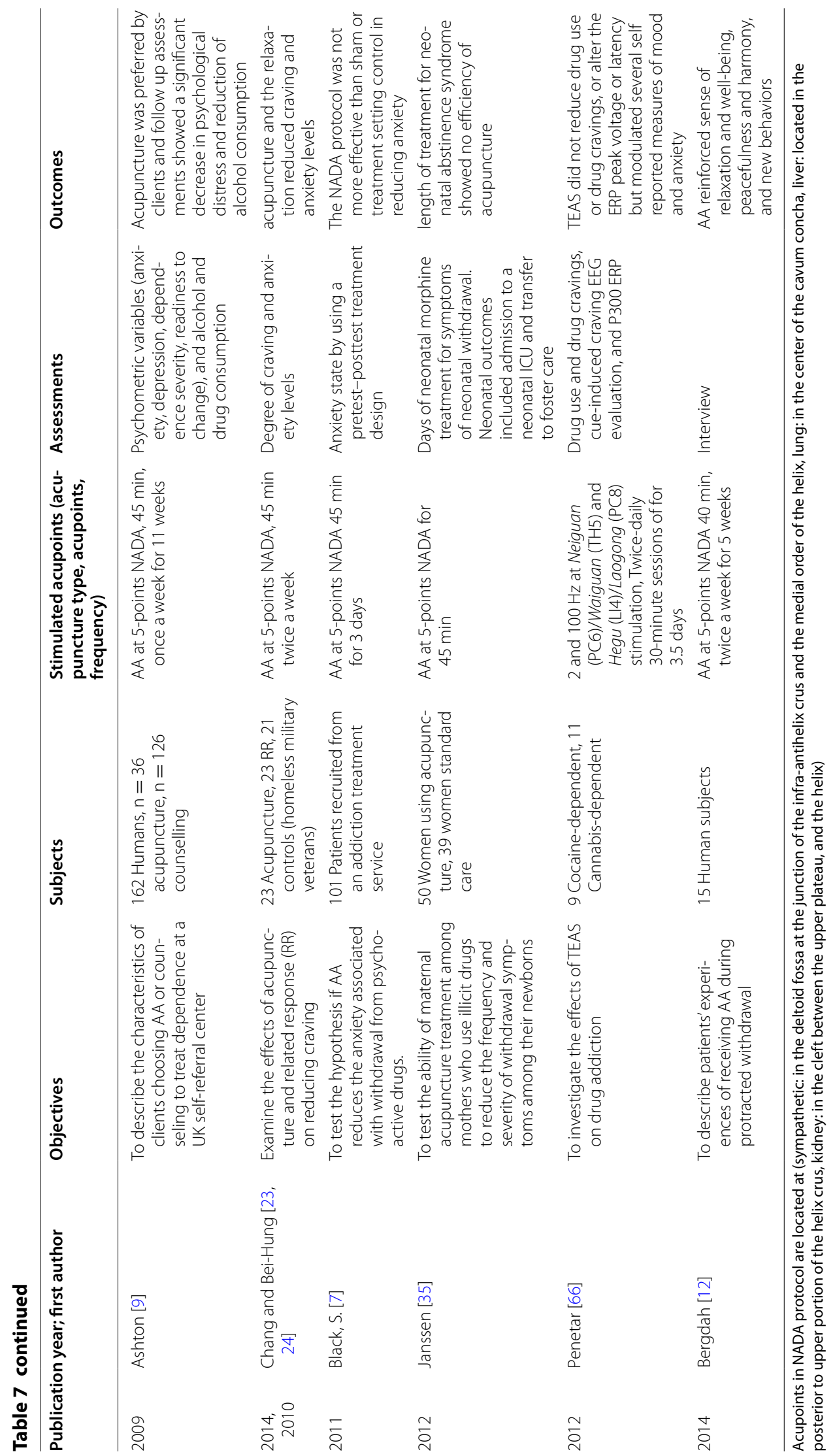


indicate that acupuncture at Shenmen (HT7), Zusanli (ST36), and Sanyinjiao (SP6) acupoints can affect druginduced physiological activities.

\section{Authors' contributions}

FEM, FI, RAR, and TS designed and conceived the study. FEM, RR, TS, Fl, and RAR carried out the article searches. FEM performed the statistical analysis. FEM and TS wrote the manuscript. FI, RAR, and $\mathrm{HH}$ revised the manuscript. All authors read and approved the final manuscript.

\section{Author details}

1 Department of Biomedical Engineering, Faculty of Engineering, University of Malaya, 50603 Kuala Lumpur, Malaysia. ${ }^{2}$ Centre for Innovation in Medical Engineering, Faculty of Engineering, University of Malaya, 50603 Kuala Lumpur, Malaysia. ${ }^{3}$ Centre of Addiction Sciences, University of Malaya, 21st Floor, Wisma Research and Development, Jalan Pantai Baru, 59200 Kuala Lumpur, Malaysia. ${ }^{4}$ Shahid Beheshti University of Medical Sciences, Tehran, Iran.

\section{Acknowledgements}

We would like to acknowledge and thank the University of Malaya and Ministry of Higher Education for providing High Impact Research Grant, account codes E000007-20001 to fund this project.

\section{Competing interests}

The authors declare that they have no competing interests.

Received: 12 September 2014 Accepted: 29 March 2016 Published online: 05 April 2016

\section{References}

1. Pelletier KR, Marie A, Krasner M, Haskell WL. Current trends in the integration and reimbursement of complementary and alternative medicine by managed care, insurance carriers, and hospital providers. Am J Health Promot. 1997;12(2):112-22.

2. Jordan JB. Acupuncture treatment for opiate addiction: a systematic review. J Subst Abuse Treat. 2006;30(4):309-14. doi:10.1016/j. jsat.2006.02.005.

3. Lin JG, Chan YY, Chen YH. Acupuncture for the treatment of opiate addiction. Evid Based Complement Alternat Med. 2012; doi:10.1155/2012/739045

4. Cowan D. Methodological issues in evaluating auricular acupuncture therapy for problems arising from the use of drugs and alcohol. Acupunct Med. 2011;29(3):227-9. doi:10.1136/aim.2010.003772.

5. Organization WHO. WHO traditional medicine strategy 2002-2005. 2002

6. Cui CL, Wu LZ, Luo F. Acupuncture for the treatment of drug addiction. Neurochem Res. 2008;33(10):2013-22. doi:10.1007/s11064-008-9784-8.

7. Black S, Carey E, Webber A, Neish N, Gilbert R. Determining the efficacy of auricular acupuncture for reducing anxiety in patients withdrawing from psychoactive drugs. J Subst Abuse Treat. 2011;41(3):279-87. doi:10.1016/j. jsat.2011.04.001.

8. Cabioglu MT, Ergene N, Tan U. Smoking cessation after acupuncture treatment. Int J Neurosci. 2007;117(5):571-8. doi:10.1080/00207450500535289.

9. Ashton H, Nodiyal A, Green D, Moore B, Heather N. Acupuncture or counselling: outcomes and predictors of treatment choice in a non-statutory addiction service. J Subst Use. 2009;14(3-4):151-60. doi:10.1080/14659890802659002.

10. Avants SK, Margolin A, Holford TR, Kosten TR. A randomized controlled trial of auricular acupuncture for cocaine dependence. Arch Intern Med. 2000;160(15):2305-12. doi:10.1001/archinte.160.15.2305.

11. Bearn J, Swami A, Stewart D, Atnas C, Giotto L, Gossop M. Auricular acupuncture as an adjunct to opiate detoxification treatment: effects on withdrawal symptoms. J Subst Abuse Treat. 2009;36(3):345-9. doi:10.1016/j.jsat.2008.08.002.

12. Bergdahl L, Berman AH, Haglund K. Patients' experience of auricular acupuncture during protracted withdrawal. J Psychiatr Ment Health Nurs. 2014;21(2):163-9. doi:10.1111/.jpm.12028.
13. Berman AH, Lundberg U, Krook AL, Gyllenhammar C. Treating drug using prison inmates with auricular acupuncture: a randomized controlled trial. J Subst Abuse Treat. 2004;26(2):95-102. doi:10.1016/ s0740-5472(03)00162-4

14. Bernstein KS. The experience of acupuncture for treatment of substance dependence. In: J Nurs Scholarsh. Wiley, United States. 2000. http:// search.ebscohost.com/login.aspx?direct $=$ true\&db=mdc\&AN=12462821 \&site=ehost-live. Accessed 332.

15. Bonnette ML. Auricular transcutaneous electrical neuro-stimulation, addiction education, behavioral training, coaching support and the nicotine addiction treatment process. J Addict Nurs. 2008;19(3):130-40. doi:10.1080/10884600802305976.

16. Bullock ML, Kiresuk TJ, Sherman RE, Lenz SK, Culliton PD, Boucher TA, et al. A large randomized placebo controlled study of auricular acupuncture for alcohol dependence. J Subst Abuse Treat. 2002;22(2):71-7. doi:10.1016/s0740-5472(01)00217-3.

17. Cai X, Song X, Li C, Xu C, Li X, Lu Q. Acupuncture inhibits cue-induced heroin craving and brain activation. Neural Regen Res. 2012;7(33):260716. doi:10.3969/j.issn.1673-5374.2012.33.006.

18. Chae Y, Kang OS, Lee HJ, Kim SY, Lee H, Park HK, et al. Effect of acupuncture on selective attention for smoking-related visual cues in smokers. Neurol Res. 2010;32:S27-30. doi:10.1179/016164109x12537002793805.

19. Chae Y, Park H-J, Kang OS, Lee H-J, Kim S-Y, Yin C-S, et al. Acupuncture attenuates autonomic responses to smoking-related visual cues. Complement Ther Med. 2011;19:S1-7. doi:10.1016/j.ctim.2010.09.003.

20. Chae Y, Yeom M, Han J-H, Park H-J, Hahm D-H, Ac IS, et al. Effect of acupuncture on anxiety-like behavior during nicotine withdrawal and relevant mechanisms. Neurosci Lett. 2008;430(2):98-102. doi:10.1016/j. neulet.2007.10.026.

21. Chae YY, Yang CH, Kwon YK, Kim MR, Pyun KH, Hahm DH, et al. Acupuncture attenuates repeated nicotine-induced behavioral sensitization and c-Fos expression in the nucleus accumbens and striatum of the rat. Neurosci Lett. 2004;358(2):87-90. doi:10.1016/j.neulet.2003.12.121.

22. Chan YY, Lo WY, Li TC, Shen LJ, Yang SN, Chen YH, et al. Clinical efficacy of acupuncture as an adjunct to methadone treatment services for heroin addicts: a randomized controlled trial. Am J Chin Med. 2014;42(3):569-86. doi:10.1142/s0192415×14500372.

23. Chang BH, Sommers E, Herz L. Acupuncture and relaxation response for substance use disorder recovery. J Subst Use. 2010;15(6):390-401. doi:10.3109/14659890903580466.

24. Chang B-H, Sommers E. Acupuncture and relaxation response for craving and anxiety reduction among military veterans in recovery from substance use disorder. Am J Addict. 2014;23(2):129-36. doi:10.1111/j.1521-0391.2013.12079.x.

25. N-n Chu, Xia W, Yu P, Hu L, Zhang R, Cui C-L. Chronic morphine-induced neuronal morphological changes in the ventral tegmental area in rats are reversed by electroacupuncture treatment. Addict Biol. 2008;13(1):47-51. doi:10.1111/j.1369-1600.2007.00092.x.

26. Courbasson CMA, de Sorkin AA, Dullerud B, Van Wyk L. Acupuncture treatment for women with concurrent substance use and anxiety/ depression - an effective alternative therapy? Fam Community Health. 2007;30(2):112-20.

27. Cui GH, Ren XW, Wu LZ, Han JS, Cui CL. Electroacupuncture facilitates recovery of male sexual behavior in morphine withdrawal rats. Neurochem Res. 2004;29(2):397-401. doi:10.1023/B:NERE.0000013743.53827.ad.

28. dos Santos JG, Filev R, Coelho CT, Yamamura Y, Mello LE, Tabosa A. Electroacupuncture inhibits ethanol-induced locomotor sensitization and alters homer1 A mRNA Expression in mice. Alcohol Clin Exp Res. 2009;33(8):1469-75. doi:10.1111/j.1530-0277.2009.00977.x.

29. Escosteguy-Neto JC, Fallopa P, Varela P, Filev R, Tabosa A, Santos JG. Electroacupuncture inhibits CB1 upregulation induced by ethanol withdrawal in mice. Neurochem Int. 2012;61(2):277-85. doi:10.1016/j. neuint.2012.05.014.

30. Fallopa P, Escosteguy-Neto JC, Varela P, Carvalho TN, Tabosa AMF, Santos $J G$. Electroacupuncture reverses ethanol-induced locomotor sensitization and subsequent pERK expression in mice. Int J Neuropsychopharmacol. 2012;15(8):1121-33. doi:10.1017/s1461145711001325.

31. Gates S, Smith LA, Foxcroft DR. Auricular acupuncture for cocaine dependence. Cochrane Database Syst Rev. 2006(1). doi:10.1002/14651858.CD005192.pub2. 
32. Hou XR, Zhang RJ, Lv H, Cai XH, Xie GC, Song XG. Acupuncture at Baihui and Dazhui reduces brain cell apoptosis in heroin readdicts. Neural Regen Res. 2014;9(2):164-70. doi:10.4103/1673-5374.125345.

33. Hu AR, Lai MJ, Wei JZ, Wang LN, Mao HJ, Zhou WH, et al. The effect of electroacupuncture on extinction responding of heroin-seeking behavior and FosB expression in the nucleus accumbens core. Neurosci Lett. 2013;534:252-7. doi:10.1016/j.neulet.2012.12.021.

34. Hu L, Chu NN, Sun LL, Zhang R, Han JS, Cui CL. Electroacupuncture treatment reverses morphine-induced physiological changes in dopaminergic neurons within the ventral tegmental area. Addict Biol. 2009;14(4):431-7. doi:10.1111/j.1369-1600.2009.00163.x

35. Janssen PA, Demorest LC, Kelly A, Thiessen P, Abrahams R. Auricular acupuncture for chemically dependent pregnant women: a randomized controlled trial of the NADA protocol. Subst Abuse Treat Prev Policy. 2012;. doi:10.1186/1747-597x-7-48

36. Janssen PA, Demorest LC, Whynot EM. Acupuncture for substance abuse treatment in the downtown eastside of Vancouver. J Urban Health. 2005;82(2):285-95. doi:10.1093/jurban/jti054.

37. Jiang YP, Liu H, Xu P, Wang Y, Lu GH. Effect of electro-acupuncture intervention on cognition attention bias in heroin addiction abstinencea dot-probe-based event-related potential study. Chin J Integr Med. 2011;17(4):267-71. doi:10.1007/s11655-011-0698-y.

38. Kang OS, Kim SY, Jahng GH, Kim H, Kim JW, Chung SY, et al. Neural substrates of acupuncture in the modulation of cravings induced by smoking-related visual cues: an FMRI study. Psychopharmacology. 2013:228(1):119-27. doi:10.1007/s00213-013-3015-y.

39. Karst M, Passie T, Friedrich S, Wiese B, Schneider U. Acupuncture in the treatment of alcohol withdrawal symptoms: a randomized, placebocontrolled inpatient study. Addict Biol. 2002;7(4):415-9. doi:10.1080/1355 621021000006017.

40. Kim JH, Chung JY, Kwon YK, Kim KJ, Yang CH, Hahm DH, et al. Acupuncture reduces alcohol withdrawal syndrome and c-Fos expression in rat brain. Am J Chin Med. 2005;33(6):887-96. doi:10.1142/ s0192415x0500348x.

41. Kim MR, Kim SJ, Lyu YS, Kim SH, Lee YK, Kim TH, et al. Effect of acupuncture on behavioral hyperactivity and dopamine release in the nucleus accumbens in rats sensitized to morphine. Neurosci Lett. 2005;387(1):1721. doi:10.1016/j.neulet.2005.07.007.

42. Kim SA, Lee BH, Bae JH, Kim KJ, Steffensen SC, Ryu Y-H, et al. Periphera afferent mechanisms underlying acupuncture inhibition of cocaine behavioral effects in rats. PLoS One. 2013;. doi:10.1371/journal. pone.0081018.

43. Kunz S, Schulz M, Lewitzky M, Driessen M, Rau H. Ear acupuncture for alcohol withdrawal in comparison with aromatherapy: a randomized-controlled trial. Alcohol Clin Exp Res. 2007;31(3):436-42. doi:10.1111/j.1530-0277.2006.00333.x.

44. Lee B, Han S-M, Shim I. Acupuncture attenuates cocaine-induced expression of behavioral sensitization in rats: possible involvement of the dopaminergic system in the ventral tegmental area. Neurosci Lett. 2009;449(2):128-32. doi:10.1016/j.neulet.2008.10.089.

45. Lee B, Shim I, Lee H, Yin CS, Park HK, Yang JS, et al. Morphine-induced locomotor response and Fos expression in rats are inhibited by acupuncture. Neurol Res. 2010;32:S107-10. doi:10.1179/0161641 $09 \times 12537002794444$.

46. Lee BH, Lim SC, Jeon HJ, Kim JS, Lee YK, Lee HJ, et al. Acupuncture suppresses reinstatement of morphine-seeking behavior induced by a complex cue in rats. Neurosci Lett. 2013;548:126-31. doi:10.1016/j. neulet.2013.05.026.

47. Lee BH, Ma JH, In S, Kim HY, Yoon SS, Jang EY, et al. Acupuncture at SI5 attenuates morphine seeking behavior after extinction. Neurosci Lett. 2012;529(1):23-7. doi:10.1016/j.neulet.2012.09.020.

48. Li HY, Zhang R, Cui CL, Han JS, Wu LZ. Damage of splenic T lymphocyte proliferation and differentiation and its normalization by electroacupuncture in morphine-dependent mice mode. Evid Based Complement Alternat Med. 2011; doi:10.1155/2011/424092.

49. Li J, Sun YA, Ye JH. Electroacupuncture decreases excessive alcohol consumption involving reduction of FosB/Delta FosB levels in reward-related brain regions. PLoS One. 2012;7(7):12. doi:10.1371/journal.pone.0040347.

50. Li J, Zou YH, Ye JH. Low frequency electroacupuncture selectively decreases voluntarily ethanol intake in rats. Brain Res Bull. 2011;86(56):428-34. doi:10.1016/j.brainresbull.2011.08.013.
51. Li YJ, Zhong F, Yu P, Han JS, Cui CL, Wu LZ. Electroacupuncture treatment normalized sleep disturbance in morphine withdrawal rats. Evid Based Complement Alternat Med. 2011; doi:10.1093/ecam/nep133.

52. Liang J, Li YJ, Ping XJ, Yu P, Zuo YF, Wu LZ, et al. The possible involvement of endogenous ligands for mu-, delta- and kappa-opioid receptors in modulating morphine-induced CPP expression in rats. Peptides. 2006;27(12):3307-14. doi:10.1016/j.peptides.2006.08.011.

53. Liang J, Ping XJ, Li YJ, Ma YY, Wu LZ, Han JS, et al. Morphine-induced conditioned place preference in rats is inhibited by electroacupuncture at $2 \mathrm{~Hz}$ : role of enkephalin in the nucleus accumbens. Neuropharmacology. 2010;58(1):233-40. doi:10.1016/j.neuropharm.2009.07.007.

54. Liu S, Zhou WH, Liu HF, Yang GD, Zhao WK. Electroacupuncture attenuates morphine withdrawal signs and c-Fos expression in the central nucleus of the amygdala in freely moving rats. Brain Res. 2005;1044(2):155-63. doi:10.1016/j.brainres.2005.02.075.

55. Liu S, Zhou WH, Ruan XZ, Li RH, Lee TT, Weng XC, et al. Activation of the hypothalamus characterizes the response to acupuncture stimulation in heroin addicts. Neurosci Lett. 2007;421(3):203-8. doi:10.1016/j. neulet.2007.04.078.

56. Liu S, Zhu FL, Lai MJ, Sun LM, Liu YJ, Zhou WH. Electroacupuncture suppresses discrete cue-evoked heroin-seeking and Fos protein expression in the nucleus accumbens core in rats. Evid Based Complement Alternat Med. 2012;. doi:10.1155/2012/286404.

57. Lua PL, Talib NS. Auricular acupuncture for drug dependence: an open-label randomized investigation on clinical outcomes, healthrelated quality of life, and patient acceptability. Altern Ther Health Med. 2013;19(4):28-42

58. Lua PL, Talib NS, Ismail Z. Methadone maintenance treatment versus methadone maintenance treatment plus auricular acupuncture: impacts on patient satisfaction and coping mechanism. J Pharm Pract. 2013;26(6):541-50. doi:10.1177/0897190013489574.

59. Margolin A, Avants SK, Arnold R. Acupuncture and spirituality-focused group therapy for the treatment of HIV-positive drug users: a preliminary study. J Psychoactive Drugs. 2005;37(4):385-90.

60. Margolin A, Avants SK, Holford TR. Interpreting conflicting findings from clinical trials of auricular acupuncture for cocaine addiction: does treatment context influence outcome? J Altern Complement Med. 2002;8(2):111-21. doi:10.1089/107555302317371398.

61. Margolin A, Kleber HD, Avants SK, Konefal J, Gawin F, Stark E, et al. Acupuncture for the treatment of cocaine addiction - a randomized controlled trial. JAMA. 2002;287(1):55-63. doi:10.1001/jama.287.1.55.

62. Meade CS, Lukas SE, McDonald LJ, Fitzmaurice GM, Eldridge JA, Merrill N, et al. A randomized trial of transcutaneous electric acupoint stimulation as adjunctive treatment for opioid detoxification. J Subst Abuse Treat. 2010;38(1):12-21. doi:10.1016/j.jsat.2009.05.010.

63. Montazeri K, Farahnakian M, Saghaei M. The effect of acupuncture on the acute withdrawal symptoms from rapid opiate detoxification. Acta Anaesthesiol Sin. 2002;40(4):173-7.

64. Overstreet DH, Cui CL, Ma YY, Guo CY, Han JS, Lukas SE, et al. Electroacupuncture reduces voluntary alcohol intake in alcohol-preferring rats via an opiate-sensitive mechanism. Neurochem Res. 2008;33(10):2166-70. doi:10.1007/s11064-008-9791-9.

65. Park HJ, Kim ST, Yoon DH, Jin SH, Lee SJ, Lee HJ, et al. The association between the DRD2 Taql A polymorphism and smoking cessation in response to acupuncture in Koreans. J Altern Complement Med. 2005;11(3):401-5. doi:10.1089/acm.2005.11.401.

66. Penetar DM, Burgos-Robles A, Trksak GH, MacLean RR, Dunlap S, Lee DYW, et al. Effects of transcutaneous electric acupoint stimulation on drug use and responses to cue-induced craving: a pilot study. Chin Med. 2012;. doi:10.1186/1749-8546-7-14.

67. Rabinstein AA, Shulman LM. Acupuncture in clinical neurology. Neurologist. 2003;9(3):137-48. doi:10.1097/00127893-200305000-00002.

68. Russell LC, Sharp B, Gilbertson B. Acupuncture for addicted patients with chronic histories of arrest-a pilot study of the consortium treatment center. J Subst Abuse Treat. 2000;19(2):199-205. doi:10.1016/ s0740-5472(00)00118-5.

69. Samuels N, Gropp C, Singer SR, Oberbaum M. Acupuncture for psychiatric illness: a literature review. Behav Med. 2008;34(2):55-62. doi:10.3200/ bmed.34.2.55-64.

70. Shi XD, Ren W, Wang GB, Luo F, Han JS, Cui CL. Brain opioid-receptors are involved in mediating peripheral electric stimulation-induced inhibition 
of morphine conditioned place preference in rats. Brain Res. 2003;981(12):23-9. doi:10.1016/s0006-8993(03)02798-7.

71. Shi XD, Wang GB, Ma YY, Ren W, Luo F, Cui CL, et al. Repeated peripheral electrical stimulations suppress both morphine-induced CPP and reinstatement of extinguished CPP in rats: accelerated expression of PPE and PPD mRNA in NAc implicated. Brain Res Mol Brain Res. 2004;130(12):124-33. doi:10.1016/j.molbrainres.2004.07.016.

72. Thanavaro IL, Delicath TA. Auricular Transcutaneous Electrostimulation Therapy and Intensive Counseling for the Treatment of Smoking Cessation in a Primary Care Practice. J Addict Nurs. 2010;21 (4):215-24. doi:10.31 09/10884602.2010.515694.

73. Tian XW, Krishnan S. Efficacy of auricular acupressure as an adjuvant therapy in substance abuse treatment: a pilot study. Altern Ther Health Med. 2006;12(1):66-9.

74. Trumpler F, Oez S, Stahli P, Brenner HD, Juni P. Acupuncture for alcohol withdrawal: a randomized controlled trial. Alcohol. 2003;38(4):369-75. doi:10.1093/alcalc/agg091.

75. Wang B, Luo F, Xia YQ, Han JS. Peripheral electric stimulation inhibits morphine-induced place preference in rats. NeuroReport. 2000;11(5):101720. doi:10.1097/00001756-200004070-00024.

76. Wang GB, Wu LZ, Yu P, Li YJ, Ping XJ, Cui CL. Multiple $100 \mathrm{~Hz}$ electroacupuncture treatments produced cumulative effect on the suppression of morphine withdrawal syndrome: central preprodynorphin mRNA and p-CREB implicated. Peptides. 2011;32(4):713-21. doi:10.1016/j. peptides.2010.12.006.

77. Wen H, Cheung S. Treatment of drug addiction by acupuncture and electrical stimulation. Asian J Med. 1973;9:138-41.

78. White AR, Rampes H, Campbell JL. Acupuncture and related interventions for smoking cessation. Cochrane Database Syst Rev. 2006;. doi:10.1002/14651858.CD0000009.pub2.

79. White AR, Rampes H, Liu JP, Stead LF, Campbell J. Acupuncture and related interventions for smoking cessation. Cochrane Database Syst Rev. 2011;. doi:10.1002/14651858.CD000009.pub3.

80. White AR, Rampes H, Liu JP, Stead LF, Campbell J. Acupuncture and related interventions for smoking cessation. Cochrane Database Syst Rev. 2014;. doi:10.1002/14651858.CD000009.pub4.

81. Xia W, Chu NN, Liang J, Li YJ, Zhang R, Han JS, et al. Electroacupuncture of $2 \mathrm{~Hz}$ Has a rewarding effect: evidence from a conditioned place preference study in rats. Evid Based Complement Alternat Med. 2011; doi:10.1093/ecam/nen043.
82. Yang $\mathrm{CH}$, Yoon SS, Hansen DM, Wilcox JD, Blumell BR, Park JJ, et al. Acupuncture Inhibits GABA neuron activity in the ventral tegmental area and reduces ethanol self-administration. Alcohol Clin Exp Res. 2010;34(12):2137-46. doi:10.1111/j.1530-0277.2010.01310.x.

83. Yeh M-L, Chang C-Y, Chu N-F, Chen H-H. A 6-week acupoint stimulation intervention for quitting smoking. Am J Chin Med. 2009;37(5):829-36.

84. Yoon SS, Yang EJ, Lee BH, Jang EY, Kim HY, Choi SM, et al. Effects of acupuncture on stress-induced relapse to cocaine-seeking in rats. Psychopharmacology. 2012;222(2):303-11. doi:10.1007/s00213-012-2683-3.

85. Yoshimoto K, Fukuda F, Hori M, Kato B, Kato H, Hattori H, et al. Acupuncture stimulates the release of serotonin, but not dopamine, in the rat nucleus accumbens. Tohoku J Exp Med. 2006;208(4):321-6. doi:10.1620/ tjem.208.321.

86. Yoshimoto K, Kato B, Sakai K, Shibata M, Yano T, Yasuhara M. Electroacupuncture stimulation suppresses the increase in alcohol-drinking behavior in restricted rats. Alcohol Clin Exp Res. 2001;25(6):63S-8S.

87. Zalewska-Kaszubska J, Obzejta D. Use of low-energy laser as adjunct treatment of alcohol addiction. Lasers Med Sci. 2004;19(2):100-4. doi:10.1007/s10103-004-0307-9.

88. Zhang RJ, Cai XH, Song XG, Dong CY, Hou XR, Lv L. Normalization of ventral tegmental area structure following acupuncture in a rat model of heroin relapse. Neural Regen Res. 2014;9(3):301-7. doi:10.4103/1673-5374.128228.

89. Zhao RJ, Yoon SS, Lee BH, Kwon YK, Kim KJ, Shim I, et al. Acupuncture normalizes the release of accumbal dopamine during the withdrawal period and after the ethanol challenge in chronic ethanol-treated rats. Neurosci Lett. 2006;395(1):28-32. doi:10.1016/j.neulet.2005.10.043.

90. Mayer DJ. Acupuncture: an evidence-based review of the clinical literature. Annu Rev Med. 2000;51(1):49-63.

91. Birch S, Hesselink JK, Jonkman FA, Hekker TA, Bos A. Clinical research on acupuncture: part 1. What have reviews of the efficacy and safety of acupuncture told us so far? The. J Altern Complement Med. 2004:10(3):468-80.

92. Head KA. Peripheral neuropathy: pathogenic mechanisms and alternative therapies. Alternative medicine review. 2006;11(4):294.

93. Shi J. LU L. Traditional Chinese medicine in treatment of opiate addiction1. Acta Pharmacol Sin. 2006;27(10):1303-8.

\section{Submit your next manuscript to BioMed Central and we will help you at every step:}

- We accept pre-submission inquiries

- Our selector tool helps you to find the most relevant journal

- We provide round the clock customer support

- Convenient online submission

- Thorough peer review

- Inclusion in PubMed and all major indexing services

- Maximum visibility for your research

Submit your manuscript at www.biomedcentral.com/submit

\section{() Biomed Central}

